\title{
Erratum to: Morphological and structural changes of the placenta in mice exposed to phenol
}

\author{
Ali Louei Monfared • Zahra Tootian • \\ Simin Fazelipour • Mohammad Taghi Sheibani
}

Published online: 7 August 2012

(C) Springer-Verlag London Limited 2012

\section{Erratum to: Comp Clin Pathol}

\section{DOI 10.1007/s00580-012-1553-z}

The original version of this article inadvertently contained a mistake.

The correct corresponding author is Zahra Tootian.

The online version of the original article can be found at http://dx.doi.org/ 10.1007/s00580-012-1553-z.

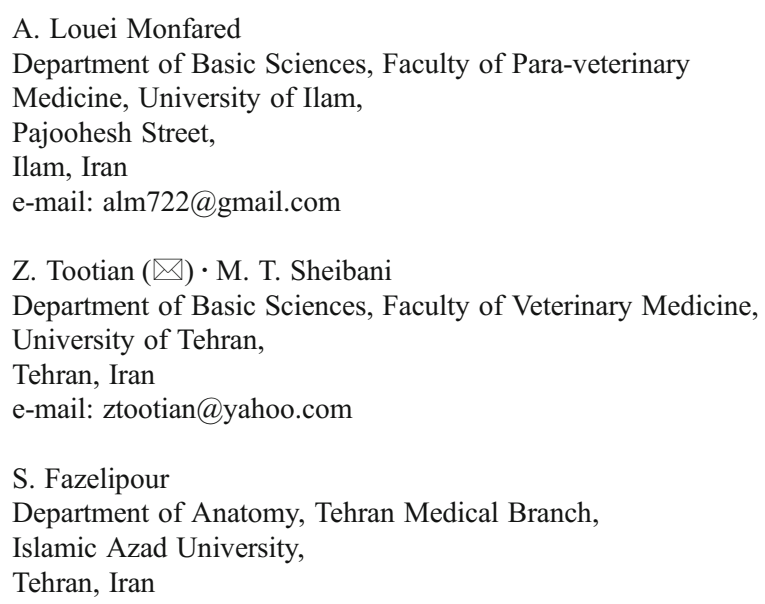

